\title{
THE SWEDISH EXPERIENCE \\ OF AN INFLATION TARGET
}

Lars E. O. Svensson

Working Paper No. 4985

\author{
NATIONAL BUREAU OF ECONOMIC RESEARCH \\ 1050 Massachusetts Avenue \\ Cambridge, MA 02138 \\ January 1995
}

A preliminary version was presented at the CEPR Workshop on Inflation Targets, Milan, November 25-26, 1994. Comments by Jonas Ahlander, Lars Hörngren [Hörngren (1994b)], Torsten Persson and workshop participants are gratefully acknowledged. This paper is part of NBER's research programs in International Finance and Macroeconomics, and Monetary Economics. Any opinions expressed are those of the author and not those of the National Bureau of Economic Research.

(C) 1994 by Lars E. O. Svensson. All rights reserved. Short sections of text, not to exceed two paragraphs, may be quoted without explicit permission provided that full credit, including $(\mathcal{C}$ notice, is given to the source. 


\title{
THE SWEDISH EXPERIENCE
}

\section{OF AN INFLATION TARGET}

\begin{abstract}
The paper gives a brief account of the Swedish experience of an inflation target in a floating exchange rate regime; identifies, documents and discusses the current problems in Swedish monetary policy and their origins; considers what can be done to remedy the problems; and draws some general conclusions. The two main current problems are the lack of credibility of the target and the significant risk that the target will be missed. The reasons for the lack of credibility include the fiscal situation, the institutional setup of monetary policy, the political division about monetary policy, and the insufficient transparency of and commitment to the current inflation-targeting policy.
\end{abstract}

Lars E. O. Svensson

Institute for International Economic Studies

Stockholm University

10691 Stockholm

SWEDEN

and NBER 


\section{Introduction}

The purpose of this paper is to give a brief account of the Swedish experience of an inflation target since its announcement in January 1993 (Section 2); to identify, document and discuss the current problems with Swedish monetary policy and their origins (Section 3 ); to consider what can be done to remedy these problems (Section 4); and to draw some general conclusions (Section 5).

\section{What has happened?}

Except for two periods, in 1914-1922 and 1931-1933, ${ }^{1}$ Sweden has had a fixed exchange rate, with occasional realignments, since 1873 . The last realignment before the recent events was on October 8,1982, when the krona was devalued by $16 \%$. From the end of 1989 the krona suffered several speculative attacks which the Riksbank fended off without any devaluations. During the speculative attack in September 1992 on ERM and Nordic currencies the krona was vigorously defended by the Riksbank, with an unprecedented marginal rate of $500 \%{ }^{2}$ The krona was attacked again in November, 1992. After having lost some 160 bn kronor in foreign exchange reserves (at the time worth about 43 bn DM), the Riksbank decided to float the krona on November $19 .^{3}$

The floating of the krona implied that the krona's traditional nominal anchor was lost. Monetary policy had to be redesigned for the new situation. Naturally there was great uncertainty about future Swedish monetary policy among the public and market participants. It appeared that the Riksbank had no contingency plan for the new situation. Riksbank staff and a few invited academics were quickly summoned by the governor to produce, under considerable time pressure, a set of position papers, published in December

\footnotetext{
${ }^{1}$ The short period in the 1930's was an interesting and fairly successful experiment of a floating exchange rate regime with a price stability target, see Fisher (1934) and Jonung (1992).

${ }^{2}$ The marginal rate, the overnight lending rate to banks, was the Riksbank's instrument until June 1, 1994, when it was replaced by a two-week repo rate.

${ }^{3}$ See Hörngren and Lindberg (1994) for a detailed account of the speculative attacks on the krona and the Riksbank's defense of it.
} 
1992 as a special issue of the Riksbank's Quarterly Review (Sveriges Riksbank (1992)). Studies of monetary policy in Canada, New Zealand and Switzerland were included in the issue, which proved to indicate in what direction the new monetary policy would turn.

On January 15, 1993, the Riksbank's governing board announced that during the fixed exchange rate regime the fixed exchange rate had been an intermediate target for achieving the goal of price stability, that under a flexible exchange rate price stability remained the goal of monetary policy, and that the Riksbank intended to achieve a CPI inflation rate for 1995 and later years of 2 percent per year, with a tolerance interval of \pm 1 percentage point per year.

When the krona was floated, the Riksbank first increased the marginal rate to 12.5 percent. In early December the marginal rate was lowered to 11.5 percent; it was then gradually lowered during 1993, parallel to a fall in long and short interest rates. Figure 1 shows the marginal/repo rate, instantaneous implied forward rates with settlement from 6 months up to 10 years, and the krona/DM exchange rate. ${ }^{4}$ The krona depreciated considerably, from 3.7 kronor/DM before the floating to 5 kronor/DM in September 1993. The inflation rate was for many observers surprisingly low (Figure 2a), given this large depreciation. The deep recession continued, with GDP growth rate and unemployment rate equal to about -2 percent per year and 8-9 percent, respectively (Figure $2 b$ and $2 d$ ). The banking sector was in a severe crisis.

Monetary policy was intensively debated. Representatives of various special interest groups (trade unions, banks, financial intermediaries, employer organizations, etc.) and many journalists advocated an aggressive monetary expansion. A few independent observers and several academic economists supported the Riksbank's more cautious expansion.

Before the krona was floated, a government committee (the Riksbank Committee) had been working on a proposal for an institutional reform of the Riksbank. Its report (SOU

${ }^{4}$ The interest rates, including the marginal/repo rate, in Figure 1 are annually compounded. The marginal/repo rate is usually quoted as a simple interest rate; hence the annually compounded marginal/repo rate in Figure 1 is a bit higher than the quoted simple rate.

See Svensson (1994a) for a discussion of why forward rates present yield curve information in a more useful way than standard yield curves, for details on the estimation of implied forward rates, and for details on some episodes during 1993-1994. 
1993:20), presented in early March 1993, recommended a legislated price stability goal and a more independent central bank. A government commission on the Swedish crisis (the so-called Lindbeck Commission) presented its report (available in English translation as Lindbeck et al. (1994)) a few days later and advocated far-reaching reforms of institutions and markets in Sweden, including the government budget process and the workings of the labor market. With regard to monetary policy it supported the Riksbank Committee's proposal about monetary independence as well as the Riksbank's cautious monetary expansion.

The political division increased about monetary policy between the social democrats and the governing liberal-conservative coalition. Although the social democrat minority in the Riksbank's governing board supported the inflation target announced in January, many social democrats advocated an aggressive monetary expansion. The social democrat minority of the Riksbank Committee had filed a reservation against the Committee's proposal when it was presented in March, 1993. Later the social democrats made clear that they would block such a proposal to the parliament, after which the government abstained from submitting the proposal. The social democrat minority in the governing board also filed a reservation against the appointment of the new governor, Urban Bäckström, when the term of the previous governor, Bengt Dennis, expired by the end of 1993 . Furthermore, some social democrats warned that they might replace Bäckström with their own candidate in case they would win the election in September 1994. Later leading social democrats announced that they would not replace Bäckström, though.

In February 1994, after the Federal Reserve's move to increase the federal funds rate, interest rates rose drastically in both U.S. and Europe. In Europe, interest rates increased the least for Germany and France, more for Britain, and most for Sweden (Figure 3 and 4). The Riksbank continued it's policy of gradually lowering the marginal rate. Some signs of a possible turnaround of the business cycle appeared during the spring.

A technical change in the implementation of monetary policy was undertaken in May. A two-week repo rate replaced the marginal rate as the instrument of monetary policy.

Towards the end of the spring inflation increased (Figure 2a). The Riksbank's June report on inflation and inflation expectations (Sveriges Riksbank (1994a)) conspicuously 
down-played the risk for increased inflation and argued that the dramatic increases in interest rates were not due to increased inflation expectations and that the inflation target was not in danger. In the summer long-term interest rates increased further, inflation forecasts warned that the inflation target would be missed, and survey inflation expectations rose.

On August 11 the Riksbank increased the repo rate for the first time since the krona was floated, explaining its move by increased inflation expectations and increased inflation pressure during the summer. Observers and market participants were largely surprised, given the message in the June report.

Throughout this period the debate was intensive about the unprecedented budget deficit and the need for fiscal consolidation (Figure 5). This debate came to dominate the debate about monetary policy proper. The deficit was blamed as the main reason why interest rates increased and why the inflation target was threatened, both by commentators and by Riksbank representatives. The mechanisms through which the budget deficit would increase interest rates were not spelled out explicitly. Commentators seemed to imply that a high budget deficit would increase both required real bond returns on bonds and inflation expectations, the latter because of the risk that inflation might be used as a means to depreciate the public debt and increase the seignorage (more on this in Section 3.2.1 below).

Social democrats were predicted to safely win the September 18 election over the liberal-conservative government coalition, although it was uncertain whether they would obtain an absolute majority in parliament. During the last few weeks before the election, social democrats were more or less forced by market unrest and rising interest rates to specify a fiscal consolidation plan. They also certified that they would continue to follow a low-inflation monetary policy, not for the time being add employment or growth to the monetary policy goal, and repeated that they would not replace the governor with their own candidate.

The social democrats won the election as predicted, failed to obtain absolute majority and formed a minority government. A new governing board of the Riksbank was appointed on October 18. As their main representative and chairman of the board, the social 
democrats appointed ex politician and previous social democrat finance minister KjellOlof Feldt. After his resignation from the social democrat government in 1990 he had left politics, distanced himself from the social democrats and become a fierce critic of lax fiscal policy, including that of his own period in government. His appointment was generally interpreted as indicating that the social democrats would not try to have direct control over monetary policy, and that the Riksbank was likely to continue its independent low-inflation policy.

The Riksbank presented a new report on inflation and inflation expectations on October 18 (Sveriges Riksbank (1994b)), with a message very different from that of the June report. Inflation expectations (measured from interest rates and from surveys), inflation pressure and inflation forecasts were all reported to have increased and to exceed the inflation target, and the report warned that there was a risk that the target was in danger. This was interpreted by observers as indicating an immanent increase in the repo rate. On October 27 the new board indeed raised the repo rate from 7.20 to 7.40 percent.

On November 5 the government presented its fiscal consolidation proposal to the parliament. Much of it had been anticipated or leaked before. The proposal had more tax increases than expenditure decreases, and it was vague about the suggested expenditure cuts which were to be specified later. Most expenditure cuts would be due to the partial indexation transfers and taxes. Many observers considered the proposal insufficient. The proposal assumed a 3 percent per year inflation rate in its calculations.

Before the referendum on whether Sweden would join the European Union or not, held on November 13, polls showed roughly equal support for Yes and No. Interest rates and the exchange rate reacted strongly to new polls, rising and depreciating, respectively, after polls showing increased support for No, vice versa after polls showing increase support for a Yes. The referendum resulted in a Yes, with 52 percent of the votes against 47 percent for a No. Interest rates and the krona moved surprisingly little after the referendum, giving the impression that the market had during the last few days anticipated a Yes, even though polls predicted only a very small majority for a Yes. One obvious interpretation of the market's reaction to the referendum polls is that increased inflation is considered less likely if Sweden joins the European Union, although other interpretations are certainly 
possible.

\section{What are the current problems?}

It seems that there are two main current problems with Swedish monetary policy. First, the inflation target lacks credibility, in the sense that inflation expectations exceed the target range. Second, at the time of writing (December 1994) there seems to be a significant risk that the inflation target for 1995 will actually be missed.

That the inflation target lacks credibility is apparent for several reasons. The Riksbank's October report on inflation and inflation expectations (Sveriges Riksbank (1994b)) detailed that inflation expectations were above the inflation target, both when measured in surveys and when inferred from interest rates. Figure 6 shows the result of a quarterly private survey of large domestic investors on the Swedish money and bond market (Aragon (1994)). Each quarter the investors are asked about their expected average inflation rate for the next 2 and 5 years respectively. The mean of their replies are shown by the thin and intermediately thick curve in Figure 6. The implied expected average inflation rate for years 3-5 is shown by the thick curve. Inflation expectations for both the next 2 years and the next 5 years have increased during the last two quarters. Whereas the inflation expectations for the next 5 years, and especially the implied inflation expectations for year 3-5, have always been above the upper 3 percent per year limit of the inflation target, inflation expectations for the next 2 years are now also above the upper limit. A new much larger survey of inflation expectations of investors, labor market organizations and head buyers by Statistics Sweden, the Swedish central statistical office, published in October gave very similar results (Statistics Sweden (1994a)).

Figures 3 and \& show forward rates for Sweden and other countries. Forward rates less a term premium can be interpreted as expected future short interest rates. Expected future short interest rates less an inflation risk premium and an expected future real rate can be interpreted as an expected future inflation rate. Even if the other components may have increased, it is inconceivable that the drastic increase in forward rates during the spring and summer, and in particular the additional increase in Swedish forward rates 
over those of other countries, is not to a considerable extent due to increased expected future inflation rates. ${ }^{5}$

That there is a significant risk that the inflation target might be missed is apparent from the fact that a number of current forecasts of future inflation exceeds the target (see Sveriges Riksbank (1994b) for details). In the government's fiscal consolidation proposal the assumed inflation rate is 3 percent per year, the upper limit of the Riksbank's target range. Since the forecasts can be interpreted as the forecasters' expectations, this is additional evidence that the inflation target lacks credibility.

The 12-month CPI inflation rate increased to 2.9 percent per year in July, just below the upper limit of 3 percent per year (Figure 2a), initiating considerable speculation in the media that the Riksbank was about to miss its inflation target (the discussion sometimes seemed to forget that the target inflation rate was a good 18 month ahead, being the December 1994-December 1995 rate). In later months, the inflation rates fell somewhat, to 2.5 percent per year in October.

Note that for satisfactory credibility it is not sufficient that inflation expectations fall just below the upper limit of 3 percent per year. Interpret expected inflation as the mean of a subjective probability distribution of future inflation, and assume that mean and the median of the distribution coincide. Then, if expected inflation is at the upper limit, the subjective probability of missing the target is 50 percent. Therefore, for satisfactory credibility the expected inflation rate should be close to the target, 2 percent per year. ${ }^{6}$ Similarly, because of the Riksbank's limited control of the price level and the uncertainty in the forecast, in order to minimize the risk of missing the target, the forecasts should of course be near the target of 2 percent per year and not just inside the target range between 1 and 3 percent per year. By the same argument, the government's assumption of a 3 percent probability can be interpreted as the government's expecting the inflation rate to exceed the upper limit by about 50 percent probability.

\footnotetext{
${ }^{5}$ See Svensson (1994a) for a details on the estimation and interpretation of forward rates, and Svensson (1993b) for details on the relevant risk premia.

${ }^{6}$ This is still "credibility in expectation." Cf. Svensson (1993a) for discussion of this and a more demanding concept of credibility, "absolute credibility."
} 


\subsection{What are the consequences of imperfect credibility and of missing the target?}

Imperfect credibility has several detrimental consequences. First, imperfect credibility makes it more costly and more difficult to achieve the target. Monetary policy has to be more contractionary and to result in a lower level of activity to counter the inflationary impulses that inflation expectations causes. ${ }^{7}$ If the target is achieved, counter to expectations, ex post real interest rates will be quite high, since they will be higher than ex ante real returns because expectations are not fulfilled and ex ante real returns are already high because monetary policy is more contractionary. Thus, the ex post real budget deficit will be higher. The increased cost of achieving the target implies that there is an increased risk that the target will be compromised and will lose general support. The increased cost of achieving the target also makes it more difficult to achieve and increases the likelihood that it will be missed. ${ }^{8}$

Second, imperfect credibility most likely allows less scope for short-run stabilization of unemployment. Any attempt to temporarily pursue a more expansionary policy in order to reduce a temporarily high unemployment will probably be interpreted as indicating increased tolerance towards medium and long run inflation, and hence induce a further fall in an already low credibility, with increased inflation expectations and increased medium and long-term interest rates as a result. This further increases the cost of a future lowinflation policy. The increased inflation expectations are also likely to result in faster nominal wage and price adjustment, which reduces the real effect of a given monetary expansion.

Missing the inflation target signficantly would also have detrimental consequences. It would most likely result in a further loss of credibility of the target, and make it even

\footnotetext{
${ }^{7}$ This is the case if the inflation is related to inflation expectations and aggregate demand/employment according to a standard expectations-augmented Phillips curve.

${ }^{8}$ The Swedish National Debt Office currently continues to issue large amounts of nominal long term debt at interest rates around 11 percent. At an inflation rate below 3 percent per year this implies that the Government of Sweden will have to pay more than a sensational 8 percent real interest rate for 10-15 years on a good part of its debt. The obvious alternative is to issue foreign currency and indexed debt, and some short term nominal debt. Commentators have hinted that the Debt Office must either be incompetent or a strong believer in high future inflation (cf. Lindgren (1994)).
} 
more costly and more difficult to achieve in the future. There would also be increased uncertainty about whether the target would be revised or even given up completely, or whether there would be renewed attempts to fulfill it in the future. It seems that there would be an increased risk of a switch to a new extended period of high inflation.

\subsection{What are the reasons for imperfect credibility?}

The reasons for imperfect credibility will be discussed under the headings of the budget deficit, the institutional setup, the political division about monetary policy, and the insufficient openness and transparency of monetary policy

\subsubsection{The budget deficit}

In the debate on economic policy debate it is often taken for granted that a high budget deficit like the Swedish one automatically brings high interest rates, high inflation expectations and subsequently high inflation. The mechanism behind this connection is rarely made explicit. A closer study shows that the effects of the budget deficit on interest rates, inflation expectations and inflation are far from automatic.

Let me briefly discuss the mechanism. A nominal bond interest rate can be seen as the sum of two components, the expected real return (to maturity) on the bond and the expected (average) inflation rate (to maturity). The expected real return can in turn be seen as consisting of an expected safe real return, a possible default premium, a possible liquidity premium, and an inflation risk premium.

A high budget deficit means large issues of government bonds. Via portfolio effects the absorption of ever larger stocks of government bonds might require a somewhat higher safe real return on Swedish government bonds. Continuous unsustainable deficits might eventually lead to a default premium. Since Swedish government bonds in foreign currency still sell at a rather modest premium over other governments' bonds, there is hardly evidence of a significant default premium yet. ${ }^{9}$ The high variability of Swedish bond inter-

\footnotetext{
${ }^{9}$ The premium on nine-year Swedish Government dollar bonds over nine-year US Treasury bonds was about 40 basis points in October 1994. The corresponding premium for Italian dollar bonds was about 50 basis points.
} 
est rates means that the return on bonds during short holding periods is very uncertain, which might result in a liquidity premium.

These components of the expected real return on government bonds might be somewhat higher for Sweden than for other countries, due to the large deficit. In principle they do not depend on monetary policy and on inflation (with the proviso that fluctuating inflation expectations cause fluctuating interest rate which may affect a liquidity premium). The remaining components, the inflation risk premium (which together with the previous components adds up to the expected real return) and the inflation expectations (which together with the other components add up to the nominal interest rate), are directly related to monetary policy. The inflation risk premium has to do with the investors' subjective uncertainty about future inflation (or more precisely, the covariance of inflation with the market portfolio, consumption or wealth, depending upon which asset pricing model is used), whereas the inflation expectations represent investors' subjective mean of future inflation.

These two latter components have to do with how monetary policy is expected to respond to budget deficit, more precisely to what extent monetary policy is expected to accommodate the budget deficit by creating higher inflation. This in turn depends on two things, the government's and the parliament's incentive to use inflation as a way to depreciate the public debt and to finance the deficit, and the government's and the parliament's power do induce the Riksbank to shift to a high-inflation policy.

The government and parliament's incentive to inflate depends on the size of the net public debt denominated in kronor and its average maturity, on the outstanding stock of currency and coins and its sensitivity to inflation (which determine how much the seignorage can be increased). The net debt in kronor is not (yet) so large, and its average maturity is not so long, that increased inflation can reduce the total debt much. Furthermore, the seignorage can not be increased much, since the volume of notes and coins outstanding is rather modest. The incentive to inflate also depends on the degree of indexation of expenditures and revenues. The new government's proposal to de-index part of expenditures and taxes actually creates a strong new incentive to inflation as a means to reduce the deficit. 
The government and parliament's influence over monetary policy depends on the goal and independence of the Riksbank. This leads to a discussion of the institutional setup of Swedish monetary policy.

\subsubsection{The institutional setup}

The institutional setup of Swedish monetary policy is not conducive to credibility.

There is no legislated goal for Swedish monetary policy. The current inflation target was announced unilaterally by the Riksbank's governing board in January 1993 . The board can thus change the target at any time. The new board that was appointed after the recent election has not made any announcement about its commitment to the inflation target.

The board consists of 8 members. Seven members, one of which is chairman of the board, are appointed by the parliament after each election, for the duration of the parliament, which will most likely be extended by this parliament from 3 to 4 years. The 7 members appoint the eighth member, the governor, for a period of 5 years. Thus the governor is not chairman of the board. If the vote in the board is equal, the chairman and not the governor has the decisive vote. The 7 members can at any time replace the governor without stating any reason.

After an election the ruling party or coalition can claim 4 of the 7 parliamentary appointments to the board, including the chair. With 4 votes of 8 , including the chairman's decisive vote, the ruling party or coalition can enforce its monetary policy, even without replacing the governor. Thus, drastic changes in monetary policy may occur at elections, if the parliamentary majority changes and there is political division about monetary policy. This brings me to the issue of the political division about Swedish monetary policy.

\subsubsection{Political division about monetary policy}

During the previous parliament period the ruling conservative-liberal coalition supported the Riksbank's monetary policy. As mentioned in section 2, the social democrat opposition and the trade union movement (which traditionally has a strong influence over the social democrats) criticized the policy and advocated a more expansionary one. They also 
objected to the Riksbank Committee's proposal for an institutional reform of monetary policy, and to the appointment of the new governor. Some social democrats argued for direct political control of the Riksbank, and for the inclusion of employment and growth in the goal for monetary policy. They also asked for better coordination of monetary and fiscal policy (without specifying what that implied).

Closer to the election the social democrats offered more conflicting signals. Sometimes they advocated low inflation, sometimes a new goal for monetary policy; eventually they promised to retain the governor and not use increased inflation to depreciate the public debt and finance the budget deficit. The social democrats suggested an inflation target expressed as "inflation of good European level," without specifying what that implied.

It seems perfectly reasonable that observers and market participants under these circumstances would assess future monetary policy and inflation performance in Sweden with considerable uncertainty, and that there would be a significant probability that the predicted social democrat victory in the election would result in an inflation-prone politically dependent Riksbank. The institutional setup of monetary policy in Sweden, with its potential for direct political control over monetary policy, inevitably makes the system very vulnerable to political division, especially before an approaching election with the possibility of a majority change in parliament.

After the election the social democrats have favorably surprised observers by appointing an independent chairman to the board, and by filling only two of their four seats with members of the parliament. ${ }^{10}$ There has been no more talk about an expansionary monetary policy. The recent government proposal for fiscal consolidation assumes a 3 percent per year inflation rate. Although this is a fairly low inflation rate, nevertheless, it is a conspicuous deviation from the Riksbank's central target of 2 percent per year. As mentioned above, if interpreted as close to the government's median projection it implies that the target is supposed to be missed by about 50 percent probability. ${ }^{11}$

\footnotetext{
${ }^{10}$ The retiring chairman of the liberal party, Bengt Westerberg, was appointed vice chairman of the board. The vice chairman has the decisive vote if the chairman is absent.

${ }^{11}$ Although one obvious interpretation of what has passed is that the social democrats have confusing and shifting views on monetary policy, there are certainly other possible interpretations. It is often the case that actions in government differ from pronouncements in previous opposition, often in the direction of being more responsible. Another interpretation is that the business cycle outlook by now is so favorable
} 
Although some uncertainty about monetary policy have been resolved after the election and the appointment of the new governing board, a fair amount of uncertainty about future policy remains, partly due to insufficient openness and transparency of monetary policy, and insufficient commitment.

\subsubsection{Insufficient openness and transparency}

In the debate on Swedish monetary policy a unified framework for the discussion of monetary policy is lacking. The Riksbank has so far not succeeded in presenting monetary policy as a technical (rather than a political) problem to achieve a specified goal, and it has not yet presented a coherent framework for the discussion of, and decisions on, monetary policy. There is no fundamental monetary policy document, which outlines the principles and details of monetary policy, its goal, indicators and instruments and specifies the commitment of the board. Formulating such a document is of course rather difficult for technical reasons, especially since Sweden's experience with the new monetary regime is so short. That should not prevent the formulation of a preliminary document that is later revised in view of increased experience.

As an example of insufficient transparency, the inflation target has not been specified and explained in an unambiguous way. There has long been uncertainty as to whether it refers to each month's 12-month inflation rate during 1995 and later, or whether it refers to the December 1994-December 1995 inflation rate. Only recently did Riksbank officials clarify that the target did not apply to 12-month inflation rates of individual months during 1995. Another problem is that the target is formulated in terms of the CPI inflation rate, without explicitly stating whether or not some changes in indirect taxes, energy prices, etc. will be excluded. This is in contrast to the formulation of inflation targets in Canada and New Zealand, where it has been made explicit what will be excluded from the CPI index. Since changes in indirect taxes may change the CPI by several percentage points, it is clear that problems may arise. The suspicion easily arises that the Riksbank might discretionary exclude some items ex post, which poses obvious

for Sweden that there is increasing consensus that there is no current need for an expansionary monetary policy. 
credibility problems. ${ }^{12}$

The most important regular document produced by the Riksbank is its inflation report, Inflation and Inflation Expectations in Sweden, currently produced 3 times a year. This document details the information available on current inflation, inflation tendencies in the future and inflation expectations. Its introduction represents a considerable improvement in the quality of monetary policy discussion. However, the status of the document is somewhat unclear. It is presented by the Riksbank's Economics Department and signed by the director of the Economics Department rather than the governor, although formally as everything produced in the Riksbank it should be considered the responsibility of the governor. As a result there is some ambiguity to what extent the governor and the board stands behind the document. Furthermore, the document has been devoid of monetary policy conclusions and clear policy recommendations in order to achieve the inflation target. An explicit inflation forecast is conspicuously absent (in contrast to what is the case for Bank of England's quarterly Inflation Report where the Bank's inflation forecast has an important role (Bank of England (1994)).

\subsection{What are the reasons why the target might be missed?}

As documented in the Riksbank's October report on inflation and inflation expectations (Sveriges Riksbank (1994b)), all available inflation forecasts indicate that the inflation target will be missed for 1995 . With hindsight, the obvious explanation is that the cautious monetary expansion of the Riksbank during 1993 and the first half of 1994 was after all too expansionary. Assuming a lag between monetary policy measures and

\footnotetext{
${ }^{12}$ An intriguing circumstance is that the Swedish CPI is constructed in such a way that the official inflation rate published by Statistics Sweden is not just the usual 12-month percentage change in the index. Instead a particular correction factor has to be used for each year, in order to correct for the yearly adjustment of weights in the index. The adjustment usually makes the official inflation rate somewhat higher than the percentage change in the index. Some years this correction factor can be above 0.2 percentage points. During 1994 it is (243.34/243.99) $-1=0.14$ percentage points (defined from the December 1993 CPI equal to 243.34 and the so called long-term link 1993 equal to 243.99 (OECD (1994), Statistics Sweden (1994b)). This implies that with rounding errors the official inflation rate for July 1994 is 2.9 percent per year, whereas the percentage change in the CPI from July 1993 to July 1994 is 2.7 percent per year. Hence it is certainly possible that the official inflation rate may exceed the 3 percent upper limit when the percentage increase in the CPI falls just below the target.

The inflation target is literally formulated in terms of "the annual increase of the consumer price index" (Sveriges Riksbank (1993)) although that should probably be interpreted as the "official inflation rate."
} 
effect on the price level of about 18 months, the monetary policy during the fall of 1993 and the spring of 1994 should be crucial for inflation during 1995. During that period the marginal rate was lowered from about 9 percent to 7 percent, and the M3 growth rate was mostly between 6 and 8 percent per year (Figure 1 and 2c). The M3 growth rate appears rather expansionary relative to a GNP growth rate of about minus 2 percent per year for 1993, plus 3-4 percent per year for June 93-June 94 (Figure 2b). On the other hand, with current inflation falling from about 5 to almost 2 percent per year, short term real interest rates were still rather high. Also, credit agregates, after a considerable contraction during spring 1993, grow very slowly. The krona, however, had depreciated considerably from about $3.7 \mathrm{kr} / \mathrm{DM}$ before the krona was floated to almost $5 \mathrm{kr} / \mathrm{DM}$. A "monetary condition index", that is to some extent used by Riksbank, attempts to assess the effect of interest rates and the exchange rate on aggregate demands. It weighs exchange rate and interest rate movements by roughly $1: 3$. That index indicated a considerable monetary expansion (Lindberg and Hansson (1994)). Ex post the net effect of monetary policy may have been too expansionary but this was certainly not easy to see ex ante, since the experience of the new monetary regime in Sweden is so short. Also, the criticism launched against the Riksbank's policy at the time was that it was far too contractionary rather then too expansionary.

With hindsight, experience and credibility, all of which were obviously lacking (for very different reasons!), it is possible that the best policy would have been more expansionary during the spring of 1993 , and less expansionary during the fall and spring of 1994. However, without credibility, the Riksbank's freedom of movement was less, and a more expansionary policy during the spring of 1993 might have been interpreted as the beginning of a new era of high inflation, hence tend to increased inflation expectations, and started to increase actual inflation.

\section{What can be done?}

What can be done to improve credibility of the inflation target and to minimize the risk that the target will be missed? Let me discuss in order what the government and 
parliament can do, and what the Riksbank can do.

\subsection{What can be done by the government and the parliament?}

The government and the parliament can improve credibility by reducing their incentive to create inflation, and by strengthening price stability as a goal for monetary policy and increasing the independence of the Riksbank.

In order to reduce the incentive to inflate, the government and parliament can achieve fiscal consolidation, stop the partial de-indexing of expenditures and taxes in its recent fiscal consolidation proposal, and reduce the proportion of net public debt that is nominated in kronor by issuing indexed and foreign currency debt. An institutional reform of the government budget process, suggested by Lindbeck et al. (1993), is already under way. The government and parliament can also reduce their incentive to inflate by increasing the flexibility of the labor market, for instance by a deregulation of the labor market, a removal of the obligatory tenure laws, and a reform of the unemployment insurance system.

In order to strengthen price stability as a goal for monetary policy and increase the independence of the Riksbank, the government and parliament can initiate the institutional reform of the Riksbank that was suggested by the Riksbank Committee (SOU 1993:20). ${ }^{13}$ A proposal along these lines from the social democrats would surely receive support from the conservative and liberal opposition and be supported by a very large majority in the parliament. This of course requires that the social democrats reconsider their previous opposition to the proposal. ${ }^{14}$ Continuous opposition by the social democrats to the institutional reform of the Riksbank must, I am afraid, most likely be interpreted as a desire to retain the inflationary option in Swedish monetary policy.

\footnotetext{
${ }^{13}$ There is one noticeable weakness in the Commission's proposal, namely regarding the accountability of the Riksbank. See Hörngren (1994a) for a discussion of accountability and of an alternative organization of the Riksbank's governing board.

${ }^{14}$ Previous opposition by social democrats and trade union representatives seem to have been to a considerable extent motivated by a belief in a long-run trade-off between unemployment and inflation (a negatively sloped long-run Phillips curve). Recent statements of social democrat and trade union economists indicate, however, that they now have accepted the overwhelming empirical evidence that rejects a long-run trade-off and thus now believe in a vertical long-run Phillips curve. This reconsideration may perhaps spill over into a more favorable attitude towards price stability and an independent Riksbank.
} 
An institutional reform of the Riksbank requires a change in the constitution, hence a decision in two consecutive parliaments. Therefore the reform cannot be completed until after the next election, which will be in September 1998 (assuming that the extension of the election period from 3 to 4 years goes through). Had political unity about such a reform been achieved during the previous parliament, the reform could have been completed shortly. As a temporary remedy the parliament could formulate an instruction to the Riksbank in the form of a law that specifies price stability as the goal for monetary policy, supports executive independence for the Riksbank in achieving the target, and in order to improve the Riksbank's accountability specifies regular public hearings where the governor reports the Riksbank's record in achieving the goal and presents the Riksbank's plans for future monetary policy.

\subsection{What can be done by the Riksbank?}

The most important thing the Riksbank can do, in order to remedy the problems mentioned above, is to pursue a monetary policy that actually fulfills the inflation target. The frank appraisal in the October report (Sveriges Riksbank (1994b)) of the risk of inflation exceeding the target, and the interest rate increases undertaken on August 11 and October 27, are strong evidence of the Riksbank's commitment to such a policy. However, there are a few additional things that the Riksbank can do, in order to increase its commitment and the openness and transparency of monetary policy.

The Riksbank and the board could increase their commitment by a policy statement that clarifies that the inflation target announced in January 1993 will be in effect for the whole extension of this parliament (and possibly longer). This might reduce uncertainty that the board might reconsider the inflation target shortly. The new board could after some time issue a Monetary Policy Declaration on what the goal of monetary policy will be and how the Riksbank plans to achieve it (in the same way that the new government traditionally issues a Government Declaration when it is elected by the parliament). ${ }^{15}$ The

\footnotetext{
${ }^{15}$ One reason for the absence of such a policy statement may be a natural desire by the Riksbank to deemphasize the importance of a change in the composition of the board and this way implicitly emphasize the continuity of monetary policy. Nevertheless, the fact remains that the board's composition has changed, that the board does exercise operational weekly control of Swedish monetary policy, and that
} 
board could contribute to openness and transparency in monetary policy by publishing the minutes from its meeting, with a lag of a few weeks, say. Similar publishing already happens abroad. In Britain the minutes from the meetings between the Chancellor of the Exchequer and the Governor of Bank of England are published with a lag. So are the minutes from the Federal Open Market Committee's meetings in the United States.

The Riksbank could try harder to present monetary policy as a technical problem of how to achieve the given inflation target. One way could be to publish a Monetary Policy Document which presents the Riksbank's view on the principles of monetary policy: how instruments, indicators and possibly intermediate targets can and will be used to achieve the goal of monetary policy. In this context the status of the Riksbank's regular report on inflation and inflation expectations could be clarified and perhaps improved. It would then be natural that the report is the Riksbank's evaluation of the current situation and its past policy, and its assessment of what future policy is necessary to make sure the target is fulfilled. Then it would be logical that the report is presented by the whole Riksbank and not just by its Economics Department.

It is clear from the discussion in section 3.2.4 that there is some scope for being more explicit about the inflation target, for instance by specifying precisely what changes (if any) in indirect taxes, energy prices, etc., will be excluded from the index.

Since monetary policy has short-term effects on output, employment and unemployment, it may be advantageous to clarify what role, if any, short-term considerations about these affect monetary policy. One possibility, suggested in Svensson (1994), is to formulate the goal for monetary policy as an explicit lexicographic ordering of long-term price stability and unemployment stabilization. (This may be particularly advantageous in Sweden, given the social democrats traditional concern about low unemployment.) Then price stability is the primary goal for monetary policy, whereas unemployment stabilization (around the natural rate of unemployment) is the secondary goal, meaning that monetary

there is nothing that prevents the board from changing the target or otherwise shifting monetary policy at any time. Another possible reason is that the board and the Riksbank may naturally want to avoid the difficult and delicate task of formulating such a document since a majority of the board are not trained economists. If this is so, this is of course an additional argument in favor of appointing a board largely composed of trained economists. 
policy may be directed towards stabilizing unemployment only if long-term price stability has been achieved and is not being endangered. This formulation raises some delicate issues, though, namely how much short-term price variability is allowed in order to stabilize unemployment, and how for instance long-term price stability should be operationally defined.

\section{Conclusions}

Together with Canada, New Zealand, Britain and Finland, Sweden has embarked upon a monetary policy with an explicit inflation target. It is of course much to early to evaluate this policy thoroughly. This paper merely reports the Swedish experience so far, together with a discussion of the current problems of Swedish monetary policy, of their origins, and of how the problems might be remedied. Some of the problems are deep in the institutional structure of Swedish economic policy and therefore not easy to correct. Although it appears technically possible to achieve and maintain the benefits of low inflation, there seem to be reasons for doubting the political system's capacity to deliver those benefits.

Inflation has recently fallen and remains low in many countries, not only countries with explicit inflation targets. A difficult but important test for the inflation target regimes will come soon when the recessions in these countries end, something that is already under way in some countries. Then we will learn whether the current inflation target regimes are more successful than other monetary policy regimes in preventing inflation from rising much above the current low levels.

\section{References}

Aragon (1994), Press Release, 17 November 1994, Aragon Securities Fondkommision AB, Stockholm.

Bank of England (1994), Inflation Report, November 1994, Bank of England, London.

Fisher, Irving (1934), Stable Money. Published 1935 in Britain under the title of Sta- 
bilised Money: A History of the Movement, George Allen \& Unwin, London.

Hörngren, Lars (1994a), "Centralbanken och penningpolitikens mål" ("The Central Bank and the Goal of Monetary Policy", in Swedish), i Stabilitet og Langsiktighet: Festskrift till Herman Skainland, Norges Bank, Oslo, 134-154.

Hörngren, Lars (1994b), "The Swedish Experience of an Inflation Target: Comments," Sveriges Riksbank, Stockholm.

Hörngren, Lars, and Hans Lindberg (1994), "The Struggle to Turn the Swedish Krona into a Hard Currency", in Johnny Åkerholm and Alberto Giovannini (eds.), Exchange Rate Policies in the Nordic Countries, Center for Economic Policy Research, London.

Jonung, Lars (1992), "Swedish Price-Stabilization Policy, 1931-1939: The Riksbank and Knut Wicksell's Norm," Monetary Policy with a Flexible Exchange Rate, Sveriges Riksbank, Stockholm, 25-39.

Lindbeck, Assar, Per Molander, Torsten Persson, Olof Petersson, Agnar Sandmo, Birgitta Swedenborg and Niels Thygesen (1994), Turning Sweden Around, MIT Press, Cambridge, MA.

Lindberg, Hans, and Bengt Hansson (1994), "Monetary Indices - Indicators for Monetary Policy", Quarterly Review, 1994:3, Sveriges Riksbank, Stockholm.

Lindgren, Ragnar (1994), "Vad sysslar riksgälden med?" ("What Is the Debt Office Doing ?", in Swedish), Finanstidningen, 13 October 1994, Stockholm.

OECD (1994), Sources and Methods - Consumer Price Indices, OECD, Paris.

SOU 1993:20, Riksbanken och prisstabiliteten (The Riksbank and Price Stability, in Swedish), Report to the government, Allmänna förlaget, Stockholm.

Statistics Sweden (1994a), Inflation Expectations for Sweden, Press Release, 7 October 1994, Stockholm. 
Statistics Sweden (1994b), Konsumentprisindex (Consumer Price Index), October 1994, Statistics Sweden, Stockholm.

Svensson, Lars E.O. (1993a), "The Simplest Test of Inflation Target Credibility," IIES Seminar Paper No. 560 (NBER Working Paper No. 4544).

Svensson, Lars E.O. (1993b), "Term, Inflation and Foreign Exchange Risk Premia: A Unified Treatment," IIES Seminar Paper No. 548 (NBER Working Paper No. 4544).

Svensson, Lars E.O. (1994a), "Estimating and Interpreting Forward Rates: Sweden 19931994," IIES Seminar Paper No. 579 (NBER Working Paper No. 4871).

Svensson, Lars E.O. (1994b), Penningpolitiska alternativ för Sverige (Monetary Policy Alternatives for Sweden, in Swedish), Report No. 14 of the Treasury's Medium Term Survey 1995, Allmänna förlaget, Stockholm.

Sveriges Riksbank (1992), Monetary Policy with a Flexible Exchange Rate, Sveriges Riksbank, Stockholm.

Sveriges Riksbank (1993), Press Release, 15 January 1993.

Sveriges Riksbank (1994a), Inflation and Inflation Expectations in Sweden, June 1994, Sveriges Riksbank, Stockholm.

Sveriges Riksbank (1994b), Inflation and Inflation Expectations in Sweden, October 1994, Sveriges Riksbank, Stockholm. 
Figure 1

Forward Rates, Marginal/Repo Rate and Exchange Rate, Sweden

9 Dec 1992 - 30 Nov 1994

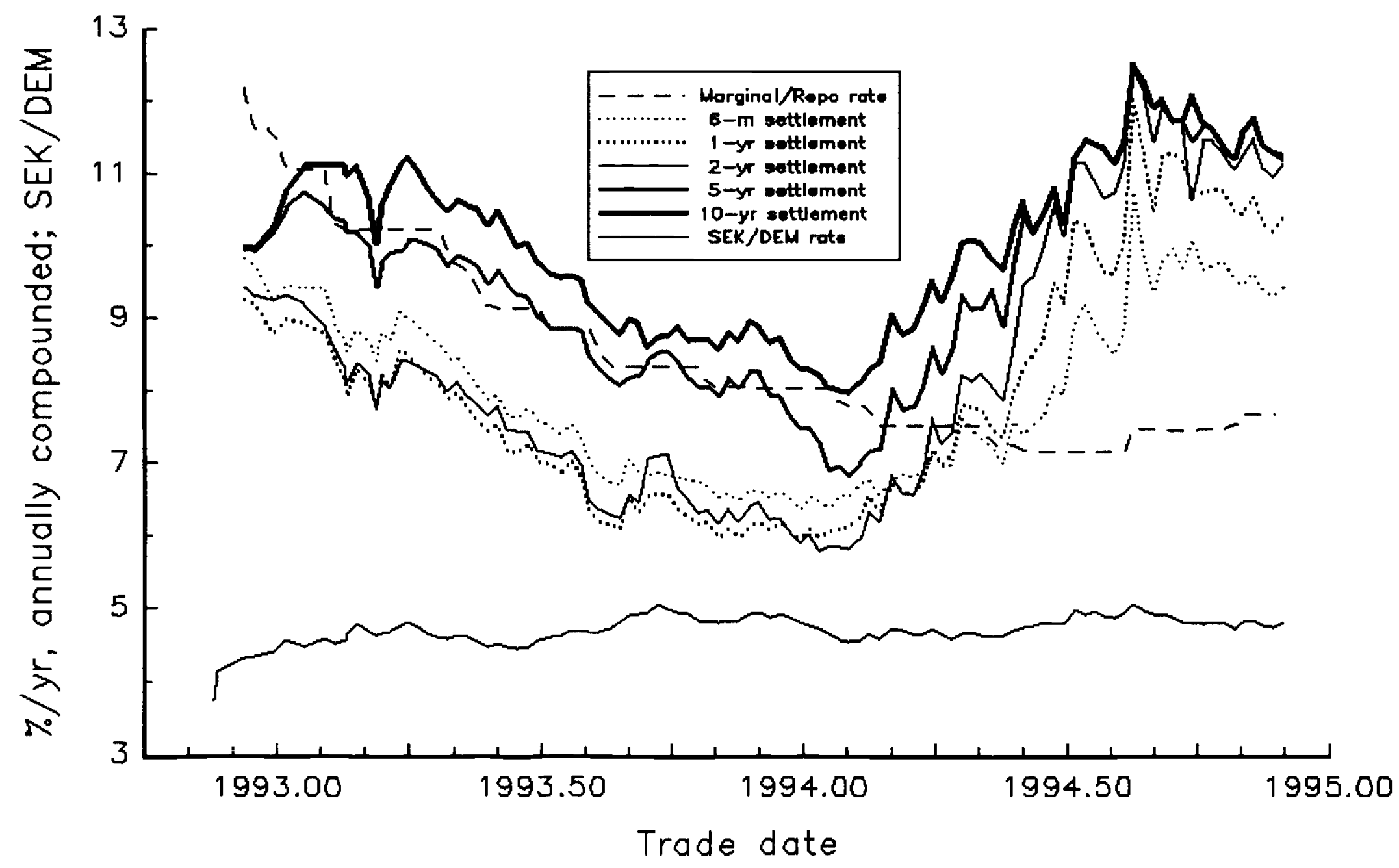


Figure 2a. 12-month Inflation Rate

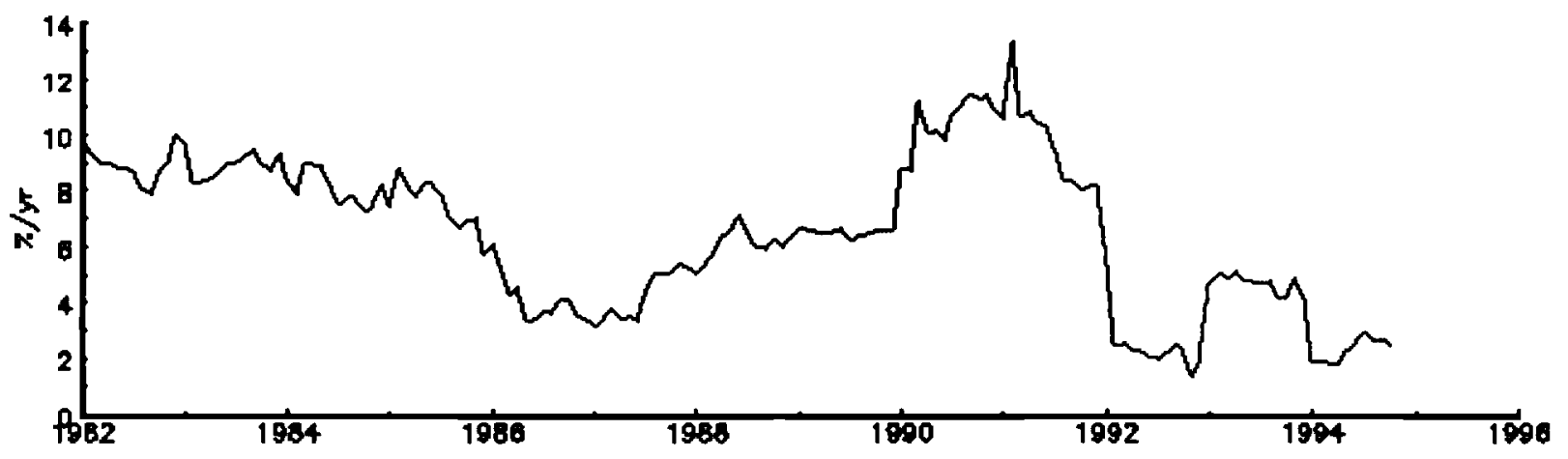

Figure Lb. 12-month GDP Growth Rate

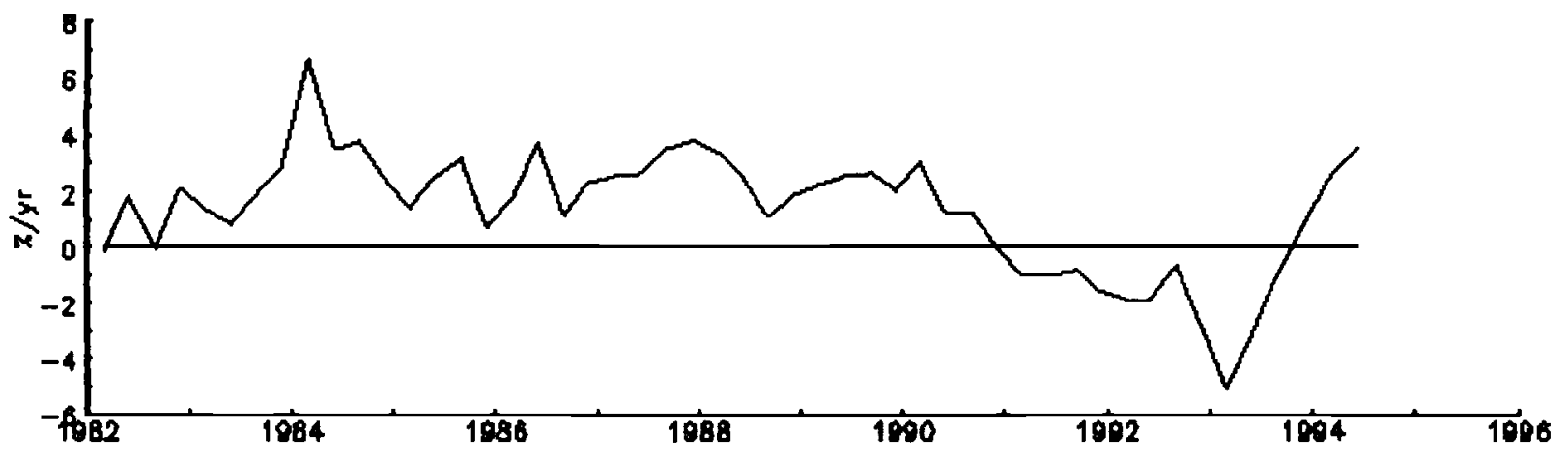

Figure 2c. 12-month M3 Growth Rate

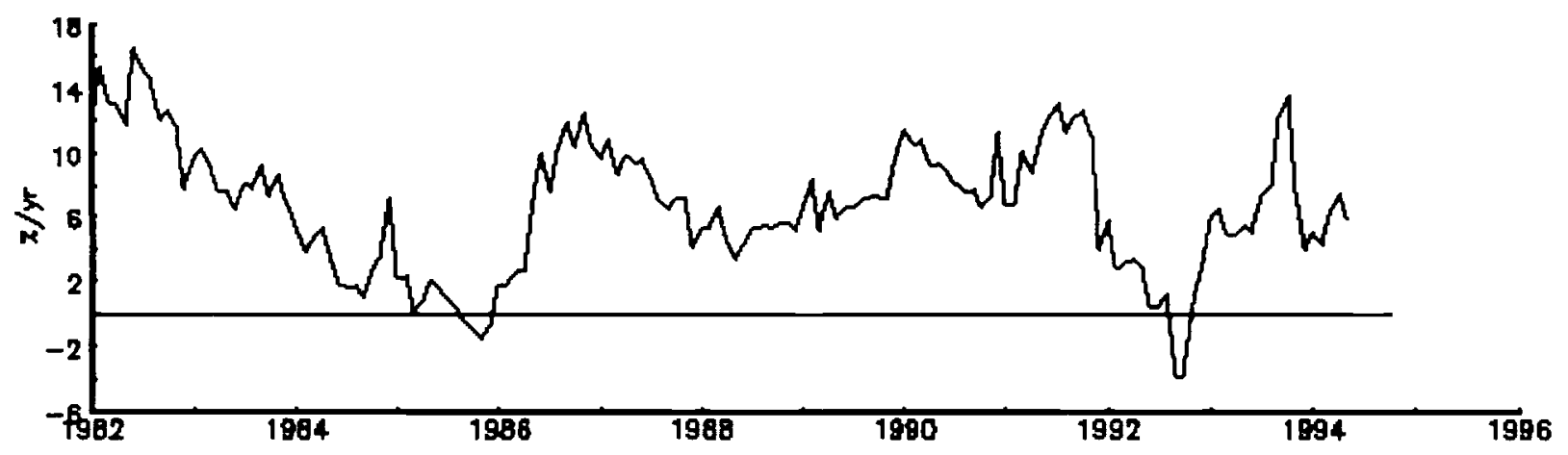

Figure id. Unemployment Rate

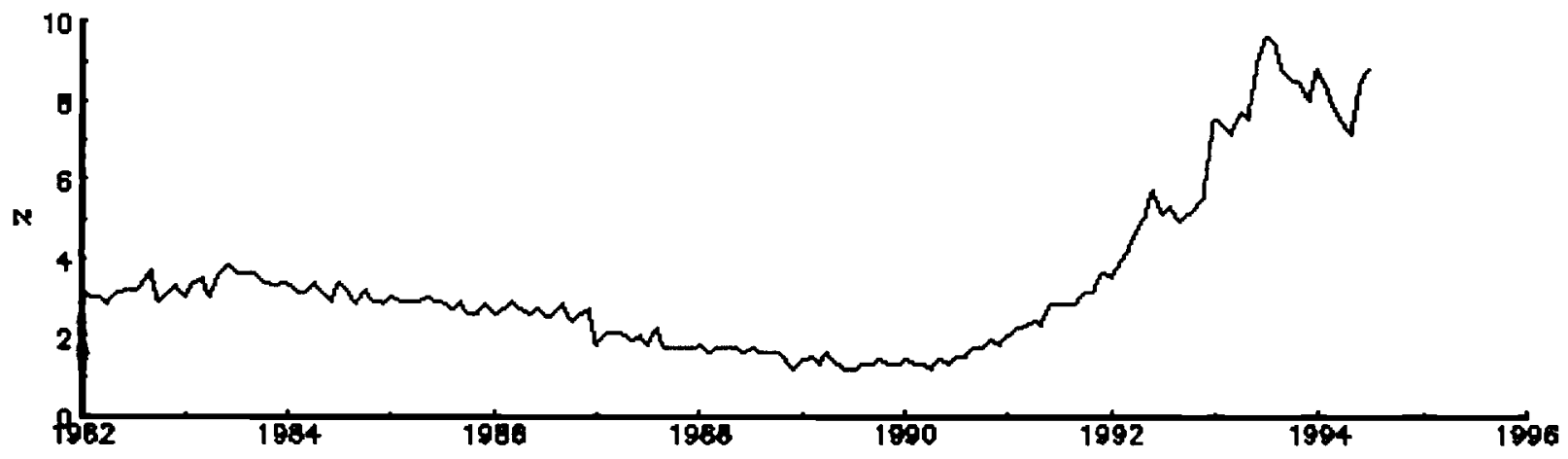


Figure 3

Forward Rates and Marginal/Repo Rate, Sweden and Germany

9 Dec 1992 - 30 Nov 1994

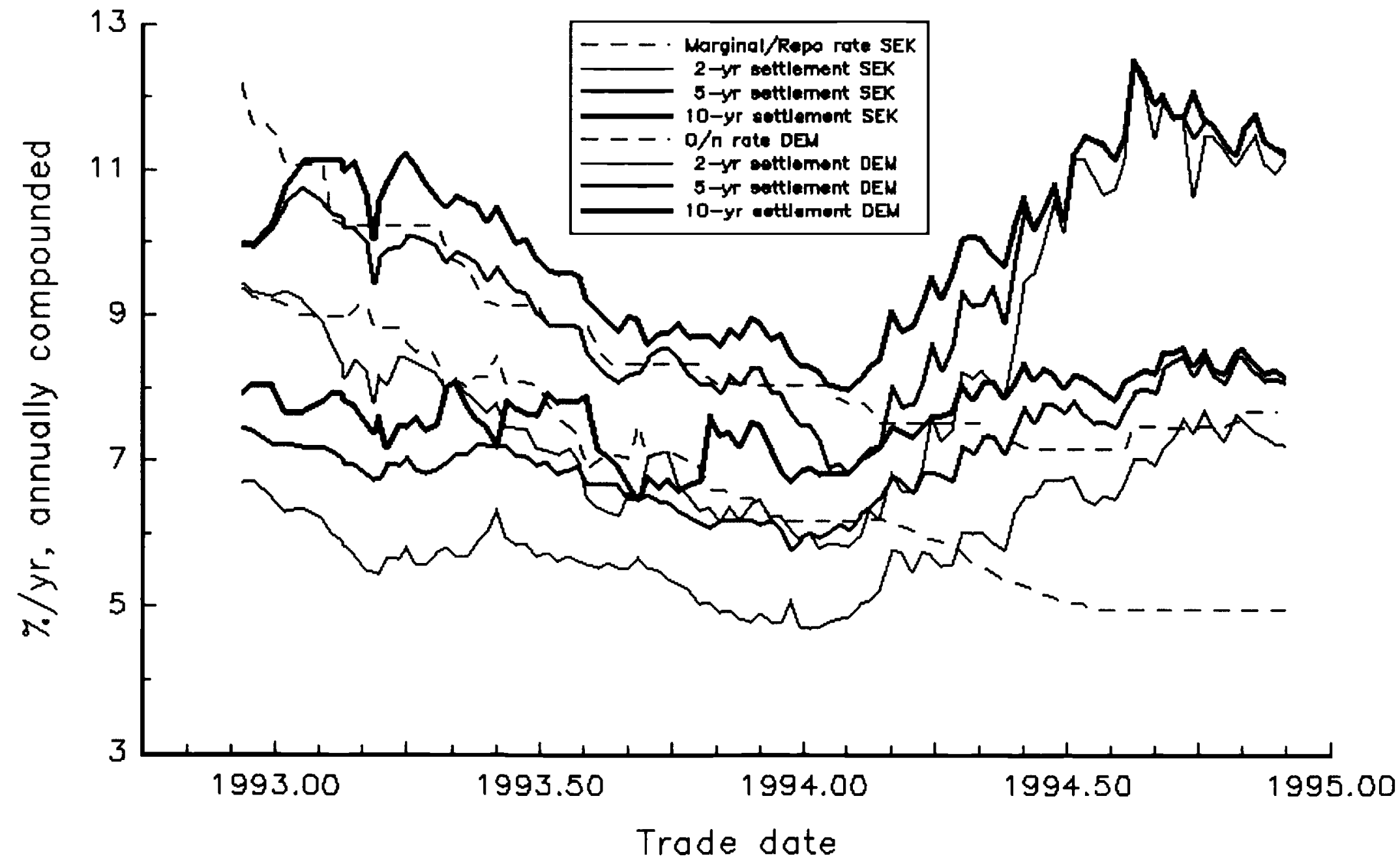


Figure 4. Forward Rates by Trade Date 30 Jun 1993 20 oct 1993
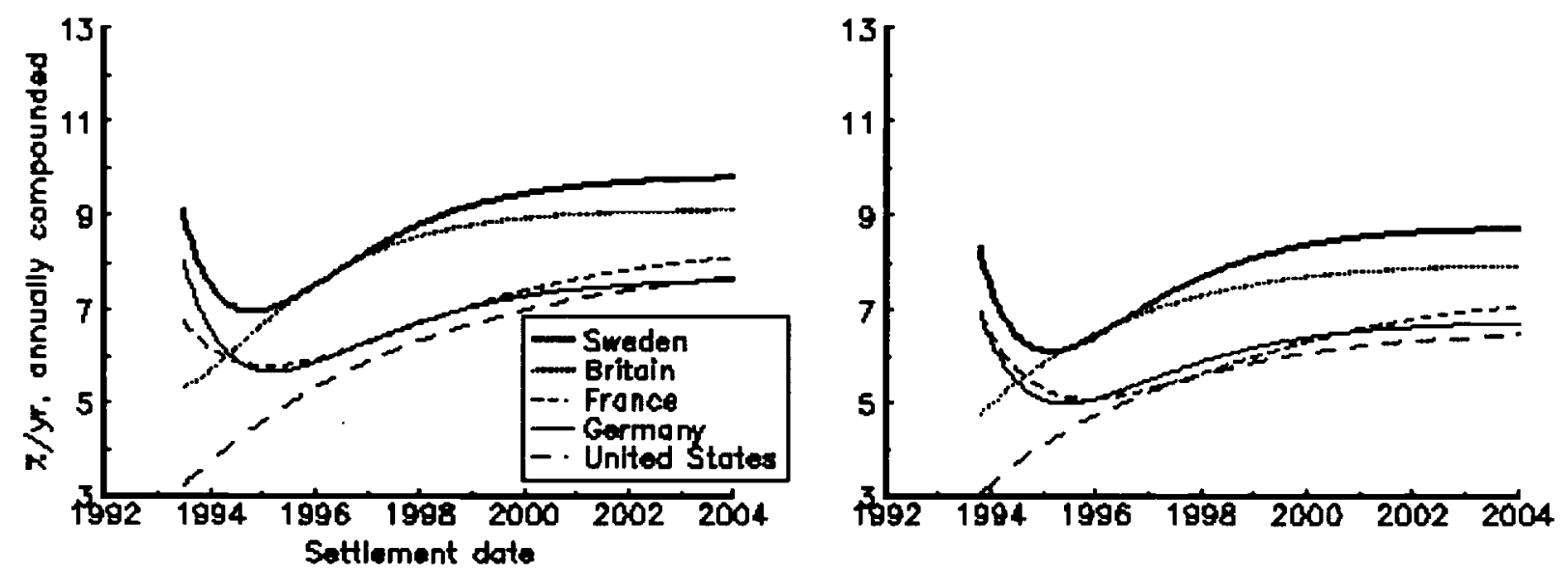

31 Aug 1994

2 Nov 1994
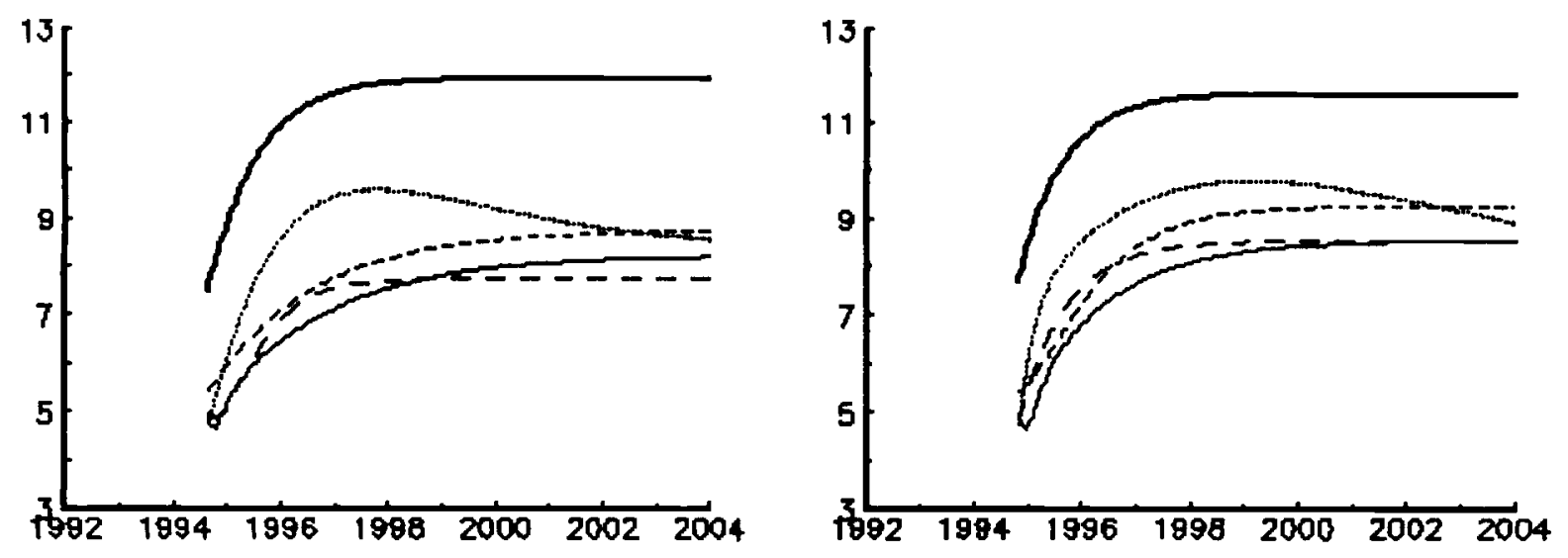

23 Nov 1994

\section{Nov 1994}
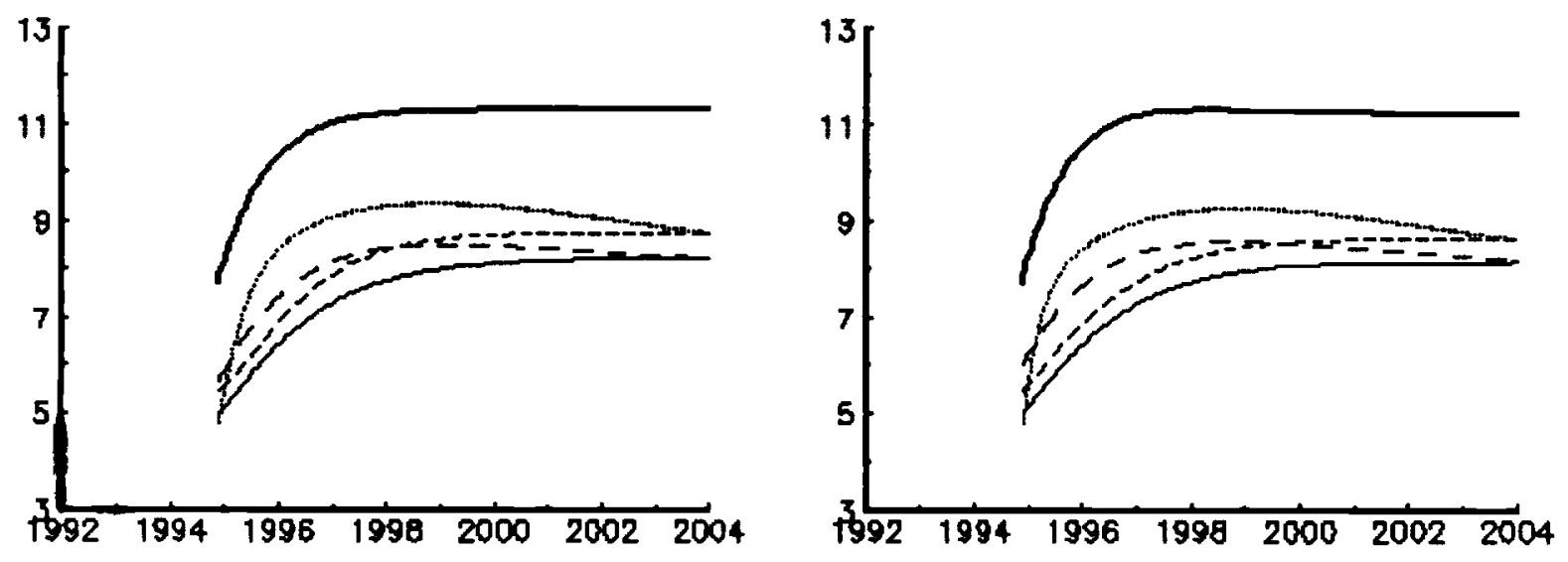
Figure 5

Budget Surplus, Share of GDP

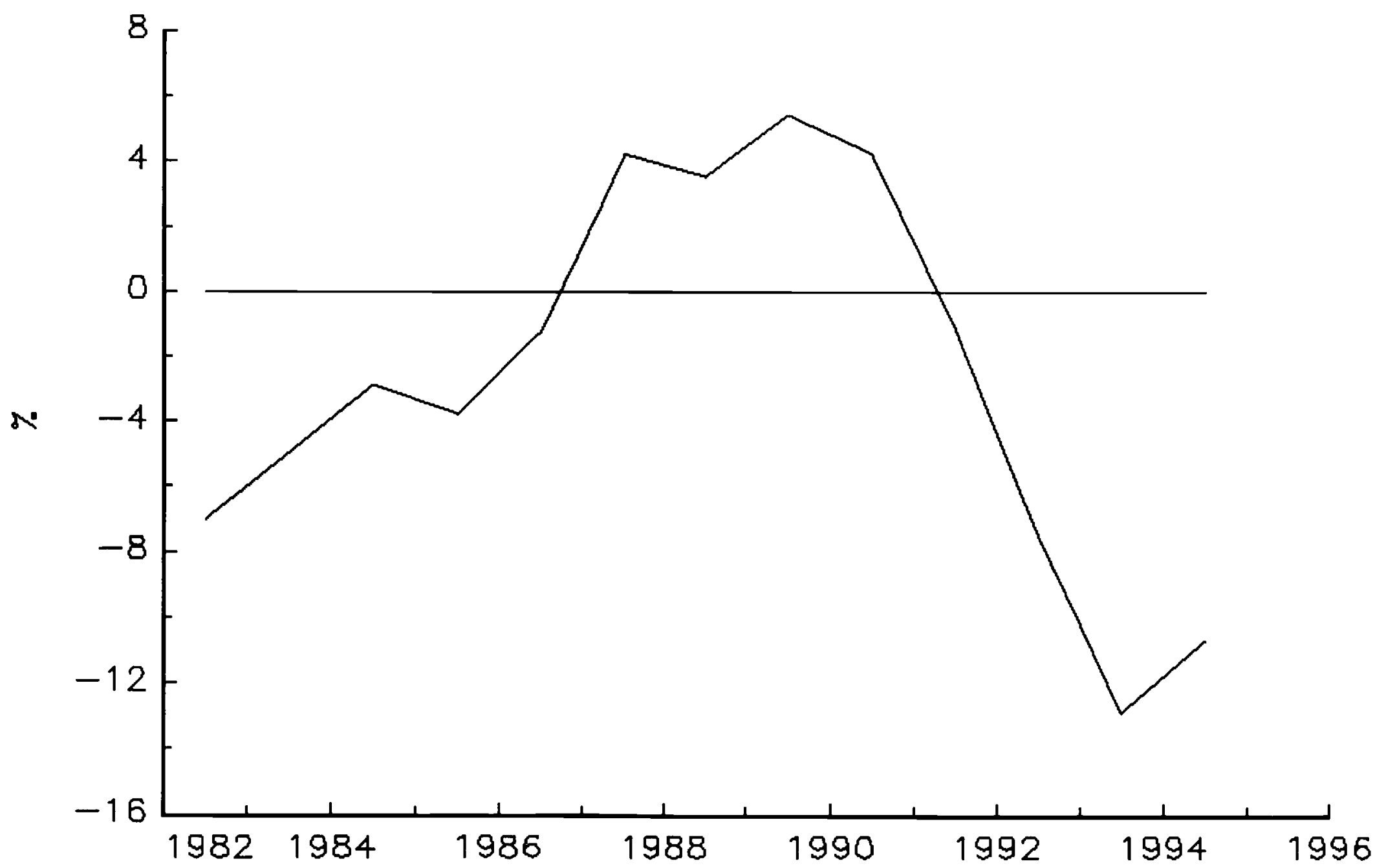


Figure 6. Expected Average Future Inflation Rate Source: Aragon Securities Fondkommission $A B$

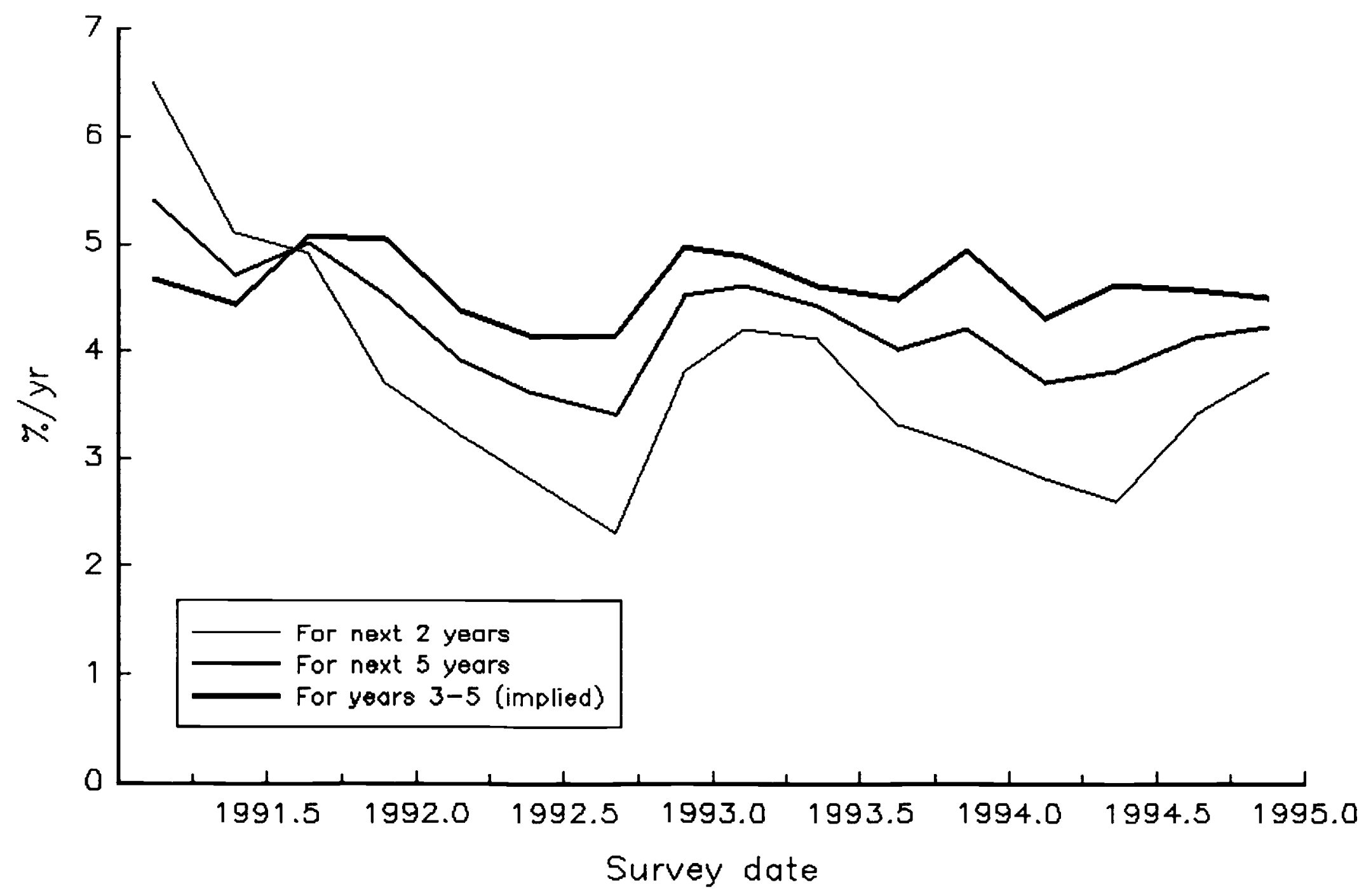

